\title{
ANALYSIS AND OPTIMIZATION OF DUAL-HEATING SYSTEM COSTS
}

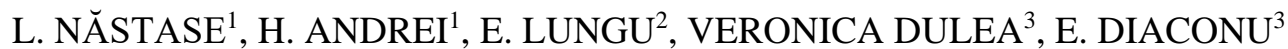 \\ Doctoral School of Engineering ${ }^{1}$, Faculty of Science and Arts ${ }^{2}$, Faculty of Electrical Engineering, Electronics and \\ Information Technology ${ }^{3}$, Valahia University of Targoviste, Romania \\ E-mail: nastase@gmail.com,hr_andrei@yahoo.com_emil12_99@yahoo.com, veronicadulea81@gmail.com, \\ emy_diaconu@yahoo.com
}

\begin{abstract}
The importance of the heating systems is given both by the quality brought to the social life and from the point of view of pollution. Environmental pollution, global energy crisis as well as global energy policy and our gas heating systems. This motivating reason for the heating system, in terms of their viability and pollution reductions, is the future. In this article a dual heating system is presented, while an electric heating system and one of the gases, the care is coordinated by a monitoring and control system. The operating strategy of the two systems is dictated by an algorithm and a cost optimization function. The use of a dual heating system is the result of comparative results regarding the measurement of the measures and the simulation of the algorithm.
\end{abstract}

Keywords: dual-heating system, analysis, optimization, energy consumption, concept, costs

\section{INTRODUCTION}

For the energy producers as well as for the domestic, industrial or public consumers, at present the problem of reducing the energy consumption necessary for the heating of the enclosures, be they houses, commercial spaces, public or industrial spaces (warehouses, production halls, offices, etc.) [1-2].

According to national statistics, $32 \%$ of domestic users are still connected to the centralized system, and the rest are disconnected and use various heating methods from conventional to unconventional. Of these, $42 \%$ use gasfired boilers, $9 \%$ solid-fuel boilers, $5 \%$ power plants, $6 \%$ other heating methods that use electricity, and the rest use the classic solid fuel system (stoves) [3-4].

Implementation of the solution in small and mediumsized enterprises could lead to a significant impact in terms of reviving the economy by reducing the production price. Currently in the spaces heated only by gas, wood or biomass plants, the implementation of the dual system with a power plant would reduce. significantly, the emissions emitted and thus a significant reduction of the pollution degree due to the heating systems [5-6] would be obtained. The main advantages of the dual heating system proposed by the present work and using two types of thermal power plants with primary agent methane gas and electricity, are:

- Its special efficiency provided by the programmable automaton and the connection to the database so that the most economical way of working between the 2 used systems will be chosen in real time;

- Use of the same hydraulic heating system (heaters installation);
- Increased degree of automation, monitoring and control;

- Reliability and assurance of the safety of the premises heating;

- The possibility of using renewable energy sources.

\section{DUAL-HEATING SYSTEM COMPONENTS}

The system of monitoring and control of the heating of the commercial spaces and of the houses refers to the rational use of two types of plants, one on methane gas, wood, coal or biomass and the other electricity, which act to heat the same precincts [7-8]. This strategy is adapted to the daily realities of our country, in which more than $56 \%$ of users use gas or solid fuel plants, and the introduction of a power station in parallel with them leads to the optimization of energy consumption and the reduction of expenses. The monitoring and control system has as main objectives [9]:

- Increasing the efficiency of the energy consumption necessary to heat the precincts by implementing an algorithm and operating program based on the predetermined choice of hours and the temperature at which the space must be heated and on the optimized choice of operating hours per type of boiler (the one on wood, gas or biomass and electricity) depending on the unit price of energy suppliers (for example GDF Suez for methane gas or Electrica SA for electricity).

- Reducing the financial expenses that in the context of the current economic crisis is a necessary measure of capital conservation for both individuals and especially for small and medium enterprises where the costs of heating during the cold season are much higher;

- Reduction of the emissions of pollutants by operating in proportion of approximately $50 \%$ of the time of the power plant on electricity.

The system is structured on 5 main hardware components shown in Figure 1:

1. Heating system (precinct/living space), is the location that will benefit from the heat generated by this dual heating system. Through the two plants that will operate alternately, depending on the program for which the owner chooses, the ambient temperature inside the building will be kept constant;

2. Gas boiler;

3. Power plant. The final decision regarding the alternation of the functioning of the two systems will be made by the owner accordingly to his need. Both plants will be connected to the same conventional heating system consisting of pipes, radiators, fittings, etc. 
4. The communication interface between the two control units (programmable logic controller - PLC) is the application that will fully control the operating time regime and the alternation.

5. The microcontroller that controls the operation will be programmed through a computer.

6. Monitoring system equipped with temperature sensors [10].

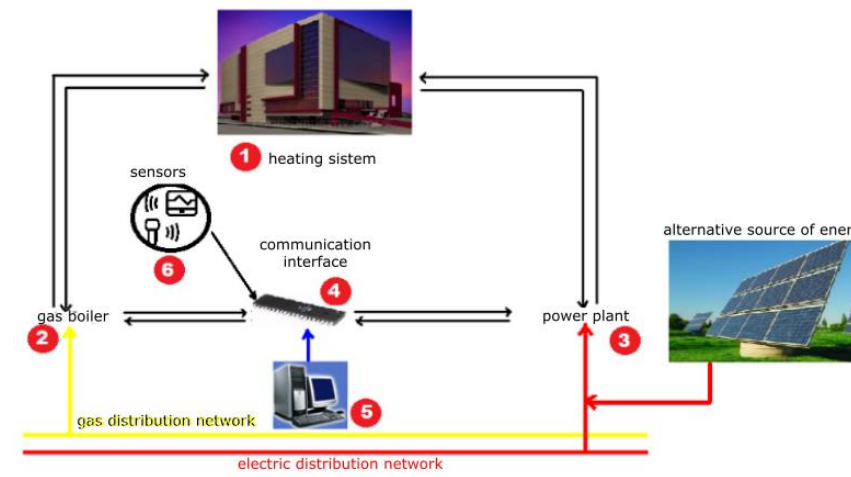

Figure 1. Monitoring and control system of the precincts heating

\section{DATA ACQUISITION SYSTEM}

For better accuracy of the measured data we divided the four chambers into two groups so room 1 and 2 were assigned to the gas boiler and rooms 3 and 4 were assigned to the power plant. For separating the system into two groups, sense valves were used so that at the time of the measurements the two groups of rooms functioned as two independent heating systems that operated simultaneously.

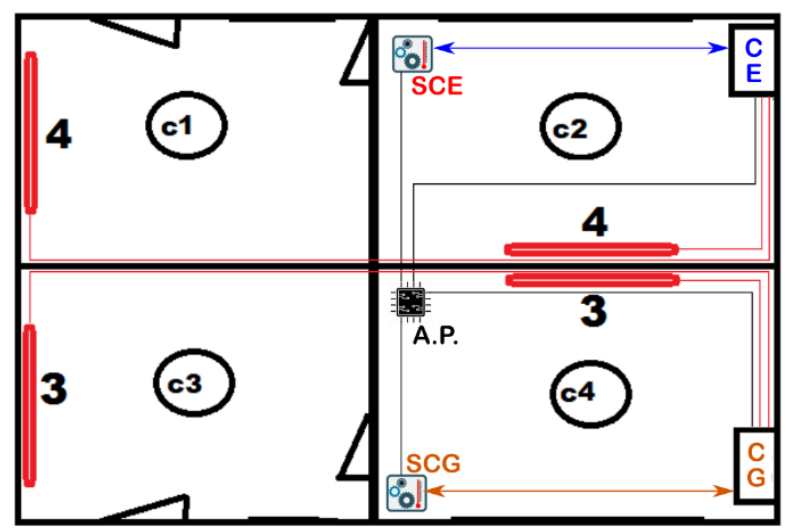

Figure 2. Enclosure layout and central and heaters location

Thus, the heating system shown in Figure 2 is made up as follows:

$-\mathrm{c} 1$ and $\mathrm{c} 2$ are the rooms heated with power plant $-c 3$ and $c 4$ are the rooms with gas central heating

-CE - power plant

-CG - gas central

-SCE - indoor heated sensors with power plant

-SCG - gas sensors heated with gas boiler

-AP - automatically programmable which controls the dual heating system
Measurements of the electrical parameters were made for two types of boilers, one on gas (IMMERGAS EOLO STAR $24 \mathrm{KW}$ ) and one electric (PROTHERM $24 \mathrm{~kW}$, $400 \mathrm{~V})$, which heated the same, symmetrical enclosures, each with a surface area of 50mp during on the same day. The initial temperature of the enclosure was $17 \mathrm{C}$ and the temperature at which the data acquisition was stopped was $22 \mathrm{C}$. The results of the measurements and their analysis are presented below.

Like the surface, number of radiators, air volume the four enclosures are identical. A separate heating was performed for $1+2$, respectively $3+4$, and the measurements presented in Tables 1 and 2 respectively were made.

With the help of the optimization function (3), a simulation was carried out in Matlab, for the heating of the enclosures 1 and 2, with a dual system consisting of the two gas and electric plants located in these enclosures and which were controlled by the AP according to the algorithm of optimization. With the help of the AP, it controls the valve system through which, for a period of time, the operation of one of the plants is closed, leaving it to operate on the other.

The information collected in the tables in the form of the one in Table 1 and 2 respectively are processed according to mathematical models in close collaboration with the information taken from the online databases of the National Energy Regulatory Authority, the National Regulatory Authority in the field of Natural Gas and those of the Administration. National Meteorology, in conjunction with the data collected by the sensors of the dual heating system helps us to calculate our own heating costs and we can make a forecast regarding the future period.

In order to calculate the cost of electricity in case of nonuse of the dual heating system (that is, of the nonoptimized use of the power plant), the following formula will be used which will generate the values in the third column of Table 1:

$$
\mathrm{C}_{\mathrm{el}}=\sum_{z=1}^{z} z \cdot\left(\sum_{t=1}^{24} t_{1} \bullet C V_{1} \bullet P_{1}\right)
$$

where:

$-\mathrm{P}_{1}$ represents the power consumed by the power plant in the time period $\mathrm{t}_{1}$, in $\mathrm{kW}$;

$-\mathrm{CV}_{1}$ represents the price of electricity, expressed in lei / $\mathrm{kWh}$;

$-t_{1}$ the daily operating time of the power plant, which may not be equal to 24 hours for periods when the enclosure temperature is equal to or higher than the prescribed one; $-\mathrm{z}$ represents the number of days of operation of the power plant; 
A similar formula is used to determine the cost of gas and electricity consumption in the case of the gas boiler, with which the values in column 2 of Table 2 will be generated:

$$
\mathrm{C}_{\mathrm{cg}}=\sum_{z=1}^{z} z\left(\sum_{t=1}^{24}\left(t_{2} \bullet C V_{2} \bullet P_{g a z}+t_{2} \bullet C V_{1} \bullet P_{2}\right)\right)
$$

where:

- $\mathrm{P}_{\text {gaz }}$ represents the power consumed by the gas boiler during the time period $\mathrm{t}_{2}$, in $\mathrm{mc}$;

- $\mathrm{CV}_{2}$ represents the price of methane gas, expressed in lei $/ \mathrm{mc}$;

$-\mathrm{P}_{2}$ is the electric power consumed by the gas boiler in the time period $\mathrm{t}_{2}$, in $\mathrm{kW}$;

$-\mathrm{CV}_{1}$ represents the price of electricity, expressed in lei / $\mathrm{kWh}$;

$-t_{2}$ the daily operating time of the boiler on gas, which may not be equal to 24 hours during periods when the temperature of the enclosure is equal to or higher than the prescribed one;

- $\mathrm{z}$ represents the number of days of operation of the gas boiler.

Table 1. Data measured during the period January 1 January 31 for the gas and power plants

\begin{tabular}{|c|c|c|c|c|c|}
\hline \multirow{3}{*}{ Date } & \multicolumn{2}{|c|}{ Temperature } & \multicolumn{2}{|c|}{ Total consumption } & \multirow{3}{*}{\begin{tabular}{|c|} 
Total consumption \\
Electricity \\
$\mathrm{kw} / \mathrm{h}$
\end{tabular}} \\
\hline & Day & Night & Gas & Electricity & \\
\hline & 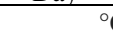 & & $\mathrm{mc}$ & $\mathrm{kw} / \mathrm{h}$ & \\
\hline 1-Jan & 12 & -2 & 9.77 & 1.09 & 30.4 \\
\hline 2-Jan & 7 & 0 & 9.82 & 1.01 & 30.91 \\
\hline 3-Jan & 7 & 3 & 8.43 & 0.99 & 26.58 \\
\hline 4-Jan & 6 & 0 & 10.36 & 0.98 & 32.63 \\
\hline 5-Jan & 7 & -2 & 10.85 & 1 & 34 \\
\hline 6-Jan & 14 & 0 & 8.21 & 1.02 & 25.63 \\
\hline 7-Jan & 13 & 0 & 8.59 & 0.99 & 27.07 \\
\hline 8-Jan & 8 & 1 & 8.96 & 1.1 & 28.13 \\
\hline 9-Jan & 6 & 1 & 9.78 & 1.08 & 30.54 \\
\hline 10-Jan & 5 & 1 & 10.39 & 0.98 & 32.76 \\
\hline 11-Jan & 7 & 4 & 7.91 & 0.96 & 24.99 \\
\hline 12-Jan & 5 & 1 & 10.3 & 1.01 & 32.56 \\
\hline 13-Jan & 1 & -2 & 13.17 & 0.98 & 41.14 \\
\hline 14-Jan & -2 & -7 & 16.9 & 1.17 & 52.65 \\
\hline 15-Jan & -5 & -7 & 18.6 & 1.2 & 58.17 \\
\hline 16-Jan & -2 & -8 & 17.36 & 1.29 & 54.44 \\
\hline 17-Jan & 6 & -5 & 12.73 & 1.15 & 40.38 \\
\hline 18-Jan & 9 & -1 & 9.84 & 1 & 30.94 \\
\hline 19-Jan & 8 & -1 & 9.91 & 1 & 31.24 \\
\hline 20-Jan & 3 & -1 & 11.8 & 1.07 & 37.24 \\
\hline 21-Jan & 1 & -1 & 12.59 & 1.11 & 39.53 \\
\hline 22-Jan & 1 & -1 & 12.7 & 1 & 39.8 \\
\hline 23-Jan & 2 & -2 & 12.74 & 1.04 & 39.93 \\
\hline 24-Jan & 1 & -6 & 15.16 & 1.06 & 47.61 \\
\hline 25-Jan & 1 & -8 & 16.18 & 1.08 & 50.86 \\
\hline 26-Jan & 2 & -10 & 16.34 & 1.2 & 51.46 \\
\hline 27-Jan & 4 & -8 & 14.96 & 1.07 & 47.01 \\
\hline 28-Jan & 4 & -8 & 15.14 & 1 & 47.87 \\
\hline 29-Jan & 8 & -3 & 10.81 & 0.95 & 34.21 \\
\hline 30-Jan & 13 & 0 & 8.56 & 1.01 & 26.81 \\
\hline 31-Jan & 11 & -2 & 10.03 & 1 & 31.77 \\
\hline Average & 5.25806 & -2.3871 & $\begin{array}{l}11.9 \\
\end{array}$ & 1.05 & 26.34 \\
\hline
\end{tabular}

The data acquisitions were made in January 2018 with the monitoring system presented in Figure 1. Various temperature sensors, the gas meter for the gas boiler as well as the Chauvin Arnoux 8352 analyzer were used to collect the data on the consumed electricity [11].
If the proposed optimization algorithm is implemented, the data obtained by simulation are detailed in Table 3.

The comparative costs of the gas boiler, respectively the electricity of the mixed heating through the implementation of the proposed optimization algorithm are presented in the chart in Figure 3.

From Figure 3 we observe that on all days subjected to comparison, the mixed heating function (obtained by applying the optimal function) gives the best efficiency in relation to the costs of obtaining the thermal comfort [12$13]$.

Table 2. Data generated by implementing the optimization function for the period January 1 - January 31 when using the dual heating system

\begin{tabular}{|c|c|c|c|c|c|}
\hline \multirow{3}{*}{ Date } & \multicolumn{2}{|c|}{ Temperature } & \multicolumn{2}{|c|}{$\begin{array}{l}\text { Consumption cost } \\
\text { for gas boiler }\end{array}$} & \multirow{2}{*}{$\begin{array}{c}\text { Total } \\
\text { consumption } \\
\text { cost }\end{array}$} \\
\hline & Day & Night & Day & Night & \\
\hline & \multicolumn{2}{|c|}{${ }^{\circ} \mathrm{C}$} & Lei & Lei & Lei \\
\hline 1-Jan & 12 & -2 & 3.57 & 8.35 & 11.92 \\
\hline 2-Jan & 7 & 0 & 4.76 & 7.45 & 12.22 \\
\hline 3-Jan & 7 & 3 & 4.80 & 5.74 & 10.54 \\
\hline 4-Jan & 6 & 0 & 5.34 & 7.54 & 12.88 \\
\hline 5-Jan & 7 & -2 & 4.79 & 8.58 & 13.38 \\
\hline 6-Jan & 14 & 0 & 2.60 & 7.43 & 10.04 \\
\hline 7-Jan & 13 & 0 & 3.20 & 7.39 & 10.58 \\
\hline 8-Jan & 8 & 1 & 4.23 & 6.86 & 11.09 \\
\hline 9-Jan & 6 & 1 & 5.38 & 6.71 & 12.10 \\
\hline 10-Jan & 5 & 1 & 6.03 & 7.00 & 13.03 \\
\hline 11-Jan & 7 & 4 & 4.74 & 5.23 & 9.97 \\
\hline 12-Jan & 5 & 1 & 6.07 & 6.85 & 12.92 \\
\hline 13-Jan & $\frac{1}{2}$ & -2 & 7.74 & 8.52 & 16.26 \\
\hline 14-Jan & -2 & -7 & 9.58 & 11.16 & 20.74 \\
\hline 15-Jan & -5 & -7 & 11.60 & 11.31 & 22.91 \\
\hline 16-Jan & -2 & -8 & 9.65 & 11.71 & 21.35 \\
\hline 17-Jan & 6 & -5 & 5.35 & 10.39 & 15.74 \\
\hline 18-Jan & 9 & -1 & 4.09 & 7.99 & 12.09 \\
\hline 19-Jan & 8 & -1 & 4.17 & 8.11 & 12.28 \\
\hline 20-Jan & 3 & -1 & 6.68 & 8.04 & 14.72 \\
\hline 21-Jan & 1 & -1 & 7.78 & 7.83 & 15.61 \\
\hline 22-Jan & 1 & -1 & 7.81 & 7.99 & 15.80 \\
\hline 23-Jan & 2 & -2 & 7.24 & 8.51 & 15.76 \\
\hline 24-Jan & 1 & -6 & 7.83 & 10.89 & 18.72 \\
\hline 25-Jan & 1 & -8 & 7.90 & 11.90 & 19.80 \\
\hline 26-Jan & 2 & -10 & 7.17 & 12.92 & 20.09 \\
\hline 27-Jan & 4 & -8 & 6.56 & 11.81 & 18.38 \\
\hline 28-Jan & 4 & -8 & 6.54 & 12.02 & 18.56 \\
\hline 29-Jan & 8 & -3 & 4.21 & 9.11 & 13.32 \\
\hline 30-Jan & 13 & 0 & 3.17 & 7.32 & 10.49 \\
\hline 31-Jan & 11 & -2 & 3.88 & 8.52 & 12.40 \\
\hline Average & 5.25806 & -2.3871 & 7.06 & 8.75 & 14.70 \\
\hline
\end{tabular}

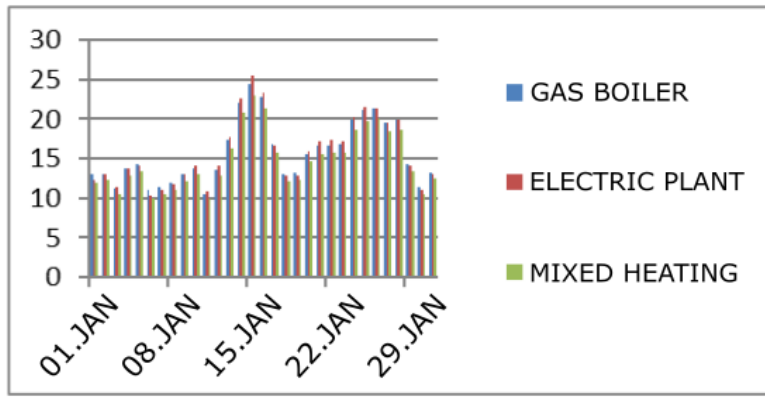

Figure 3. Chart of the consumption of electric, gas and mixed heating (optimized)

Table 3. Total costs of the three types of heating solutions and the minimum percentage of saving achieved 


\begin{tabular}{|c|c|c|c|c|}
\cline { 2 - 4 } \multicolumn{1}{c|}{} & \multicolumn{3}{c}{$\begin{array}{c}\text { Heating cost } \\
\text { gas boiler }\end{array}$} \\
\hline \multirow{2}{*}{ Date } & Gas & Electricity & Optimized & \\
\cline { 2 - 5 } & \multicolumn{3}{c|}{ Lei } & $\%$ \\
\hline 1-Jan & 12.98 & 12.39 & 11.92 & $3.94 \%$ \\
\hline 2-Jan & 13.02 & 12.99 & 12.22 & $6.30 \%$ \\
\hline 3-Jan & 11.23 & 11.42 & 10.54 & $6.55 \%$ \\
\hline 4-Jan & 13.69 & 13.83 & 12.88 & $6.29 \%$ \\
\hline 5-Jan & 14.33 & 14.14 & 13.38 & $5.68 \%$ \\
\hline 6-Jan & 10.96 & 10.3 & 10.04 & $2.59 \%$ \\
\hline 7-Jan & 11.44 & 11.05 & 10.58 & $4.44 \%$ \\
\hline 8-Jan & 11.96 & 11.79 & 11.09 & $6.31 \%$ \\
\hline 9-Jan & 13 & 13.07 & 12.1 & $7.44 \%$ \\
\hline 10-Jan & 13.74 & 14.1 & 13.03 & $5.45 \%$ \\
\hline 11-Jan & 10.55 & 10.8 & 9.97 & $5.82 \%$ \\
\hline 12-Jan & 13.64 & 14.05 & 12.92 & $5.57 \%$ \\
\hline 13-Jan & 17.29 & 17.81 & 16.26 & $6.33 \%$ \\
\hline 14-Jan & 22.13 & 22.69 & 20.74 & $6.70 \%$ \\
\hline 15-Jan & 24.33 & 25.45 & 22.91 & $6.20 \%$ \\
\hline 16-Jan & 22.78 & 23.4 & 21.35 & $6.70 \%$ \\
\hline 17-Jan & 16.79 & 16.72 & 15.74 & $6.23 \%$ \\
\hline 18-Jan & 13.04 & 12.8 & 12.09 & $5.87 \%$ \\
\hline 19-Jan & 13.13 & 12.91 & 12.28 & $5.13 \%$ \\
\hline 20-Jan & 15.58 & 16 & 14.72 & $5.84 \%$ \\
\hline 21-Jan & 16.61 & 17.24 & 15.61 & $6.41 \%$ \\
\hline 22-Jan & 16.7 & 17.32 & 15.8 & $5.70 \%$ \\
\hline 23-Jan & 16.77 & 17.19 & 15.76 & $6.41 \%$ \\
\hline 24-Jan & 19.87 & 20.22 & 18.72 & $6.14 \%$ \\
\hline 25-Jan & 21.19 & 21.51 & 19.8 & $7.02 \%$ \\
\hline 26-Jan & 21.43 & 21.43 & 20.09 & $6.67 \%$ \\
\hline 27-Jan & 19.61 & 19.57 & 18.38 & $6.47 \%$ \\
\hline 28-Jan & 19.82 & 19.93 & 18.56 & $6.79 \%$ \\
\hline 29-Jan & 14.26 & 14.05 & 13.32 & $5.48 \%$ \\
\hline 30-Jan & 11.4 & 10.95 & 10.49 & $4.39 \%$ \\
\hline 31-Jan & 13.28 & 13.03 & 12.4 & $5.08 \%$ \\
\hline Average & 15.70 & 15.81 & 14.70 & $5.87 \%$ \\
\hline & & & & \\
\hline
\end{tabular}

\section{MODELING AND OPTIMIZATION OF COSTS}

4.1 Calculation of the depreciation of the investment of transformation of the traditional heating system into a dual heating system

Another important objective of this paper is the calculation of the depreciation of the investment for a dual heating system.

Amortization is the way in which the acquisition cost of the fixed assets is recovered during their useful life which is usually equal to their useful life [14]. This presentation of the depreciation concept is a difficult concept to digest for a non-financier, because it also represents a calculated expense.

To make it easier to understand, depreciation is actually the gradual recovery, both fiscal and accounting, of all costs incurred with the purchase, installation, commissioning of a system, in our case the power plant, solenoid valves, the sensor system, the interface of communication and control between the two plants, the photovoltaic system on grid [15-16].

Depreciation is represented by the monthly split of the total cost of the assets subject to depreciation, and the total number of months for which the depreciation will be made is usually equal to the life of the investment [17].

Therefore, depreciation is in fact a financial process of recovering and distributing the depreciable amount for an asset during its useful life. An interpretation concept of depreciation is represented by the fact that it can be considered as a financing source that helps to renew / refurbish the asset.

According to the law 82/1991 - the accounting law there are several methods of depreciation, based on which the depreciable amount is established monthly [18].

We will consider two hypotheses for which we will use the linear damping method:

1. Calculation of the depreciation of the primary investment - we start from the premise that the enclosure already has a heating system consisting of gas and heaters, and as an investment we will consider the power plant PROTHERM $24 \mathrm{kw}, 400 \mathrm{~V}$, three solenoid valves (for hot water, for heating and flow and return), set of sensors for temperature monitoring and the communication and control interface between the two control units (AP programmable automatic).

2. Calculation of the depreciation of the primary investment from point one and of the On Grid photovoltaic system $25 \mathrm{kWp} / 125 \mathrm{~kW}$ day Benq - Fronius.

\subsection{Calculation of primary investment depreciation}

The elements that make up the fixed assets are presented in the table below (Table 4)

Table 4. The component elements of the modernization system for the transformation of the standard heating system into the dual heating system

\begin{tabular}{|l|l|r|}
\hline No. & Fixed asset & Value \\
\hline 1. & $\begin{array}{l}\text { PROTHERM 24 kW, 400V power } \\
\text { plant (including installation and } \\
\text { commissioning) }\end{array}$ & 2.400 lei \\
\hline 2. & Direction valve & 250 lei \\
\hline 3. & Set of temperature monitoring sensors & 50 lei \\
\hline 4. & $\begin{array}{l}\text { Communication and control interface } \\
\text { between the two control units (PLC) }\end{array}$ & 200 lei \\
\hline & TOTAL Depreciable value of the asset & 2.900 lei \\
\hline
\end{tabular}

According to the legal provisions the life span used in the calculation of depreciation is established according to the "Catalog regarding the classification and the normal durations of operation of the fixed assets", which is approved by "H.G. no. 2.139/2004 and is between 8 and 12 years old, being classified in class 2.1.16.5. Equipment for electrical stations and transformer stations. Equipment for thermal, electrical and nuclear power plants."

$$
\begin{gathered}
\mathrm{Aa}=\mathrm{Vaa} / \mathrm{d} \\
\mathrm{Aa}=\mathrm{Vaa} * \mathrm{raa} \\
\mathrm{raap}=(100 / \mathrm{d}) \% \\
\mathrm{raa}=\mathrm{raap} * \mathrm{Vaa} \\
\mathrm{ralp}=\mathrm{raa} / 12 \\
\mathrm{ral}=\mathrm{ralp} * \mathrm{Vaa} \\
\mathrm{Al}=\mathrm{Vaa} * \mathrm{ral}
\end{gathered}
$$

where:

Aa - annual depreciation, 
Al - monthly depreciation,

Vaa - the depreciable amount of the asset,

$\mathrm{d}$ - the duration of use of the fixed assets expressed in years,

raap - percentage annual depreciation rate,

ralp - the percentage monthly repayment rate,

raa - annual depreciation rate,

ral - monthly depreciation rate.

The depreciable value of the asset is 2,900 lei, and the life expectancy is considered to be the maximum life expectancy according to H.G. no. 2.139/2004 i.e. 12 years.

Thus, we have the following information:

$$
\begin{gathered}
\text { Vaa }=2.900 \text { lei } \\
\mathrm{d}=12 \text { years } \\
\mathrm{Aa}=2.900 / 12=241.66 \text { lei } \\
\operatorname{raap}=(100 / 12)=8,33 \% \\
\operatorname{ralp}=\text { raap } / 12=0,69 \% \\
\mathrm{Al}=31,39 \text { lei }
\end{gathered}
$$

From an accounting point of view, the amortization of the investment will be made over a period of 12 years and will represent a value of 241.66 lei/year or 31.39 lei/month.

Table 5. Total cost consumption of electrical, gas and heating (optimized), heating and the cost difference between heating and mixed heating

\begin{tabular}{|c|c|c|c|c|}
\hline Date & Gas boiler & $\begin{array}{c}\text { Power } \\
\text { Plant }\end{array}$ & $\begin{array}{c}\text { Mixed } \\
\text { heating }\end{array}$ & $\begin{array}{c}\text { economy } \\
\text { using }\end{array}$ \\
\hline 1-Jan & 12.98 & 12.39 & 11.92 & 1.06 \\
\hline 2-Jan & 13.02 & 12.99 & 12.22 & 0.8 \\
\hline 3-Jan & 11.23 & 11.42 & 10.54 & 0.69 \\
\hline 4-Jan & 13.69 & 13.83 & 12.88 & 0.81 \\
\hline 5-Jan & 14.33 & 14.14 & 13.38 & 0.95 \\
\hline 6-Jan & 10.96 & 10.3 & 10.04 & 0.92 \\
\hline 7-Jan & 11.44 & 11.05 & 10.58 & 0.86 \\
\hline 8-Jan & 11.96 & 11.79 & 11.09 & 0.87 \\
\hline 9-Jan & 13 & 13.07 & 12.1 & 0.9 \\
\hline 10-Jan & 13.74 & 14.1 & 13.03 & 0.71 \\
\hline 11-Jan & 10.55 & 10.8 & 9.97 & 0.58 \\
\hline 12-Jan & 13.64 & 14.05 & 12.92 & 0.72 \\
\hline 13-Jan & 17.29 & 17.81 & 16.26 & 1.03 \\
\hline 14-Jan & 22.13 & 22.69 & 20.74 & 1.39 \\
\hline 15-Jan & 24.33 & 25.45 & 22.91 & 1.42 \\
\hline 16-Jan & 22.78 & 23.4 & 21.35 & 1.43 \\
\hline 17-Jan & 16.79 & 16.72 & 15.74 & 1.05 \\
\hline 18-Jan & 13.04 & 12.8 & 12.09 & 0.95 \\
\hline 19-Jan & 13.13 & 12.91 & 12.28 & 0.85 \\
\hline 20-Jan & 15.58 & 16 & 14.72 & 0.86 \\
\hline 21-Jan & 16.61 & 17.24 & 15.61 & 1 \\
\hline 22-Jan & 16.7 & 17.32 & 15.8 & 0.9 \\
\hline 23-Jan & 16.77 & 17.19 & 15.76 & 1.01 \\
\hline
\end{tabular}

\begin{tabular}{|c|c|c|c|c|}
\hline 24-Jan & 19.87 & 20.22 & 18.72 & 1.15 \\
\hline 25-Jan & 21.19 & 21.51 & 19.8 & 1.39 \\
\hline 26-Jan & 21.43 & 21.43 & 20.09 & 1.34 \\
\hline 27-Jan & 19.61 & 19.57 & 18.38 & 1.23 \\
\hline 28-Jan & 19.82 & 19.93 & 18.56 & 1.26 \\
\hline 29-Jan & 14.26 & 14.05 & 13.32 & 0.94 \\
\hline 30-Jan & 11.4 & 10.95 & 10.49 & 0.91 \\
\hline 31-Jan & 13.28 & 13.03 & 12.4 & 0.88 \\
\hline TOTAL & 486.55 & 490.15 & 455.69 & 30.86 \\
\hline
\end{tabular}

If we calculate the economy produced by the use of the mixed dual heating system for January 2018, we will find that an economy of 30.86 lei was made. At a first comparison with the calculated accounting depreciation rate, we could consider that the implementation of such a system does not bring profit from the accounting point of view but is a loss generator since the monthly depreciation (31.39 lei) is greater than the economy produced by the system implementation. heating (30.86 lei). But at the same time, we must bear in mind that the measurements were made on a space of 50 square meters, but the plants used can easily heat a space at least 5 times larger than this. Thus, if we take into account the new information, we will find that the economy made by using the dual heating system for a space 5 times larger for which the purchased plant was actually designed is proportionally 5 times larger, ie $30.86 * 5=154,30$ lei. According to this calculation it follows that the use of the dual heating system at least 7 weeks a year in the cold season (which in our country is at least 16 weeks) produces a greater savings than the depreciation calculated according to the accounting norms.

If we consider the fact that the cold season in our country is at least 16 weeks and the heating space is $250 \mathrm{~m}^{2}$, then we can recalculate the time to recover this investment by reducing it considerably, to 5 years.

Thus, it is found that although the accounting depreciation is 12 years, the effective recovery of the investment is made in 5 years resulting in an ROI of $255 \%$ of the investment's lifetime.

4.3 Calculation of primary investment and photovoltaic system amortization $25 \mathrm{kWp} / 125 \mathrm{~kW}$ day Benq - Fronius

The elements that make up the fixed asset are presented in Table 6.

Table 6. The component elements of the modernization system for the transformation of the standard heating system in a dual heating system including photovoltaic on grid system

\begin{tabular}{|l|l|r|}
\hline No. & Fixed asset & Value \\
\hline 1. & $\begin{array}{l}\text { PROTHERM 24 kW, 400V power plant } \\
\text { (including installation and } \\
\text { commissioning) }\end{array}$ & $\begin{array}{r}2.400 \\
\text { lei }\end{array}$ \\
\hline 2. & Direction valve & 250 lei \\
\hline 3. & Set of temperature monitoring sensors & 50 lei \\
\hline
\end{tabular}




\begin{tabular}{|l|l|r|}
\hline 4. & $\begin{array}{l}\text { Communication and control interface } \\
\text { between the two control units (PLC) }\end{array}$ & 200 lei \\
\hline 5. & $\begin{array}{l}\text { On Grid photovoltaic system 25 kWp / } \\
125 \mathrm{~kW} \text { day Benq - Fronius }\end{array}$ & $\begin{array}{r}67.000 \\
\text { lei }\end{array}$ \\
\hline & TOTAL Depreciable value of the assets & $\begin{array}{r}69.900 \\
\text { lei }\end{array}$ \\
\hline
\end{tabular}

According to the legal provisions the life span used in the calculation of depreciation is established according to the "Catalog regarding the classification and the normal operating times of the fixed assets", which is approved by H.G. no. 2.139/2004 and is between 8 and 12 years old, being classified in class 2.1.16.5 "Equipment for electrical stations and transformer stations. Equipment for thermal, electrical and nuclear power plants." [19, 20].

The depreciable value of the asset is 69,900 lei, and the life expectancy is considered to be the maximum of the lifetime according to H.G. no. 2.139 / 2004 i.e. 12 years.

Thus, we have the following information

$\mathrm{Vaa}=69.900$ lei

$\mathrm{d}=12$ years

Aa $=69.900 / 12=5825$ lei

Raap $=(100 / 12)=8,33 \%$

ralp=raap $/ 12=0,69 \%$

From an accounting point of view, the amortization of the investment will be made over a period of 12 years and will represent a value of 5825 lei / year or 485.42 lei / month.

If in the previous paragraph 4.4.4.1 we talked about the amortization of the investment represented by the power plant, solenoid valves, sensors and the interface of communication and control between the two plants, in this paragraph we analyze also the depreciation of a photovoltaic system that produces electricity and the surplus of electricity is delivered to the grid as green energy.

Thus, the photovoltaic system has the following component elements:

1. SMA On Grid Inverter [21],

2. Photovoltaic panels Black Frame Polycrystalline Benq $265 \mathrm{~W}$,

3. Roof fixing system,

4. AC / DC protection panel,

5. Cable connection set.

For the analysis regarding the recovery of the investment made with the photovoltaic system on grid (ROI - return of investment), we used the dedicated software PV * sol to be able to generate the efficiency of the photovoltaic cells used depending on the location where they will be mounted (longitude and latitude) [22-24]. The location where the measurements were made is located in Ploiești having the following coordinates: latitude $44.95577^{\circ}$ and longitude $25.98904^{\circ}$, see Figure 6.

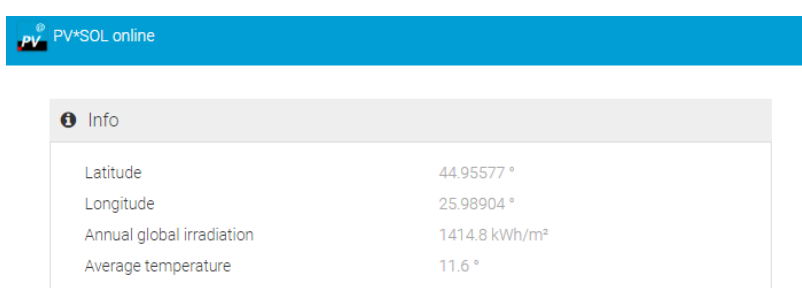

Figure 6. Location coordinates of on grid photovoltaic system

By determining the location coordinates of the photovoltaic system, in conjunction with the analysis performed by the dedicated software PV * sol, we determined the electricity production realized by the photovoltaic system. The results of the analysis are detailed in Figures 7-9.
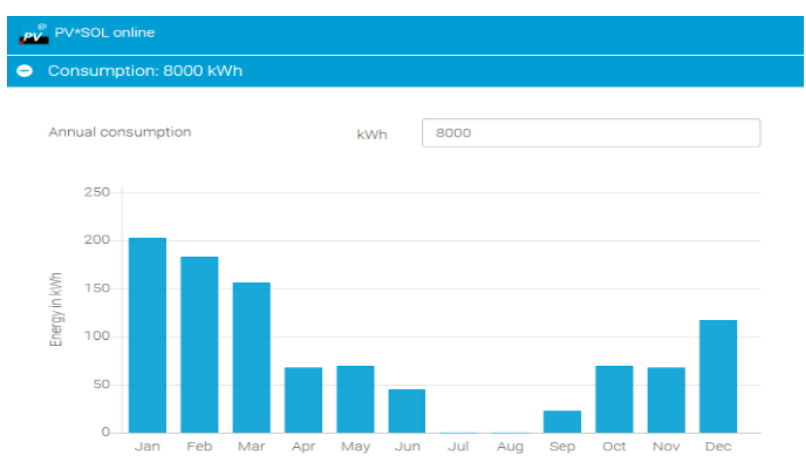

Figure 7. Electricity consumption chart used for the heating of the enclosures generated by the $\mathbf{P V} *$ sol software

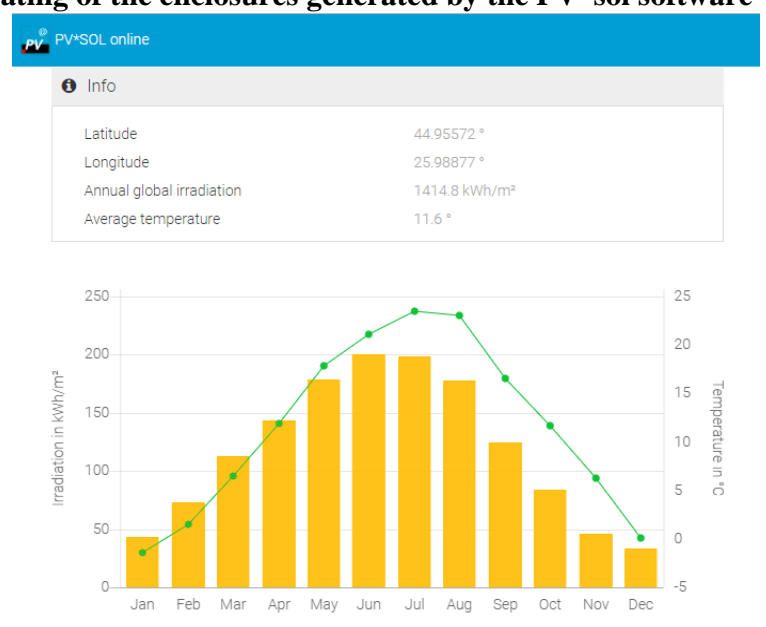

Figure 8. Solar radiation chart per sqm according to the geographical coordinates generated by the $\mathbf{P V} *$ sol software

According to the data generated by the $\mathrm{PV}^{*}$ sol software we have an annual electricity production of $34,556 \mathrm{kWh}$, and the system uses for its own consumption (for heating the premises of its own production) $3648 \mathrm{kWh}$, and the remaining $4481 \mathrm{kWh}$ needed for heating are purchased from the grid. By using the photovoltaic system, $\mathrm{CO} 2$ emissions are reduced by $18,487 \mathrm{~kg} /$ year.

This system will produce energy as follows:

1. The average daily energy produced is $94 \mathrm{kWh}$.

2 . The monthly average energy produced is $2,879 \mathrm{kWh}$.

3 . The average annual energy produced is $34,556 \mathrm{kWh}$. 

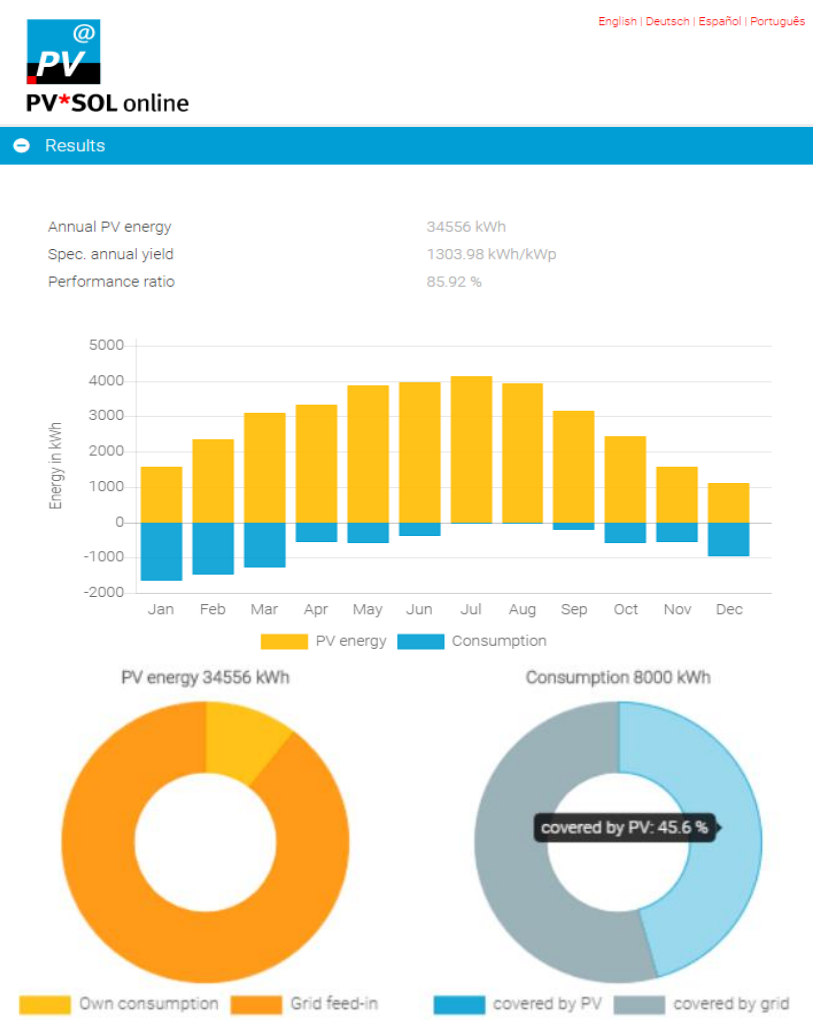

Figure 9. Annual chart of energy production and consumption using On Grid photovoltaic system generated by $\mathrm{PV} *$ sol software

If we provided monthly on the grid the energy produced by the photovoltaic system at an average cost of 0.3 lei / $\mathrm{kWh}$, we would register a monthly income of 863.70 lei. On a simple calculation, considering that the monthly depreciation calculated is 485.42 lei for the entire system including the power plant, solenoid valves, temperature sensors, the communication and control interface between the two plants, we find that the investment in the a photovoltaic system, which results in a ROI twice the accounting depreciation.

If we extrapolate and no longer analyze depreciation as an accounting phenomenon and calculate the time to recover the investment, we find that we will recover the investment of the photovoltaic system and the power plant in about 6 years and 9 months ( 81 months). At the same time, it must be taken into account that the photovoltaic system has a life of about 25 years, which will lead to a profit 3 times greater than the initial investment.

In view of the conclusions made in the previous paragraph regarding the amortization of the investment regarding the power plant, solenoid valves, the temperature monitoring system and the communication and control interface between the two plants, we can consider that they are amortized by themselves by simply using the dual power system. heating, and On Grid photovoltaic system 25 $\mathrm{kWp} / 125 \mathrm{~kW}$ day Benq - Fronius will be depreciated then 6 years faster. At the same time, if we consider the fact that the Romanian village subsidizes the installation of green energy production systems with the amount of
20,000 lei, we find that the investment recovery period is reduced by 2 years, so the ROI reaches somewhere below 5 years.

\section{CONCLUSIONS}

In this article we set out to do an analysis and optimization of the costs of dual heating systems, to reduce the expenses necessary for the heating in the cold season, by introducing a new concept of heating of the premises called "dual heating system" or "dual -heating "which ensures an efficient consumption of electricity and / or heat (gas, biomass, fossil fuel, etc.), as well as autonomy and energy security.

In this respect first goal of this article is to purchases for electrical parameters, analysis of these parameters and the specific consumption of the two types of gas and electric boilers that heat the same enclosure, during the same time period and with the same initial temperature conditions.

The second one is to develop a comparative analysis of the total cost in the three scenarios of heating the premises, two independent systems and one dual.

Consequently the calculation of the period of depreciation of the investment if one considers the existence of a gas boiler and then invests in the new dual heating system, which is run by the AP according to the optimized algorithm is presented. Also, the calculation of the depreciation is continued in the case of the introduction of a photovoltaic system used to supply the dual heating system with electricity.

\section{REFERENCES}

[1] Bohi D.R., Toman N. "The Economics of Energy Security", Kluwer Academic Publishers, Boston 1996.

[2] Bahnareanu C. "Arma energetica in contextul relatiilor internationale ale inceputului de secol XXI". Editura Universitatii Nationale de Aparare Carol I, Bucuresti 2007.

[3] Volosin A. "Razboaiele energetice ale secolului XXI, Stabilitate și Securitate Regională", Editura Universității Nationale de Apărare CAROL I, Bucuresti, 2009.

[4] Kelemen G., Ursa D., “Alternativă energetică: energia solară, Tehnica Instalaţiilor”, Ed. Minos, anul IV.1/2004.

[5] Elemente de Strategie Energetică a României pentru perioada 2011 - 2035. Ministerul Economiei Economiei, 2011.

[6] Siegenthaler J. "Modern hydronic heating for residential and light commercial buildings", 2010.

[7] Peuser F.A., Remmers K.H., Schnauss M., "Solar thermal systems", Solar Praxis, Berlin, 2002.

[8] Economy and Finance Ministry, National Guide for the cost-benefit analysis. 
[9] CLC/TC8X WG 1 Technical Committee - Sec0013 "Guide to the Application of the European Standard" *** EN 50160 1st Edition (22 July, 2003).

[10] Hermina Albert, "Loss of electrical power and energy networks", Tehnical Publishing House, Bucharest, 1997.

[11] Hadar A, Marin, C, Petre, C., "Metode numerice în inginerie" Editura Politehnica Press, București 2005.

[12] Sybille G., „Theory and Applications of Power System Blockset, A MATLAB/Simulink-Based Simulation Tool for Power Systems", IEEE PES Winter Meeting 1, pag. 774-779, 2000.

[13] Arora J. S. "Guide to structural optimization. ASCE Manuals and Reports on Engineering Practice" No. 90. 1997.

[14] Dueck G., Scheuer T. "Threshold Accepting: A General Purpose Optimization Algorithm Appearing Superior to Simulated Annealing." J. Comp. Phys. 90, 1990.

[15] https://accace.ro/ce-reprezinta-si-cum-se-calculeaza -amortizarea/

[16] http://www.panourilesolare.ro/harta-solara-a-roman iei.html;

[17] http://www.sanyo.com/solar/ SANYO Component Europe $\mathrm{GmbH}$; Solar Division

[18] https://contabilul.manager.ro/a/3989/monografiecontabila-amortizarea-imobilizarilor-corporale.html

[19] Legea 82/1991 - Legea contabilitatii

[20] H.G. nr. 2.139/2004 - "Catalogul privind clasificarea si duratele normale de functionare a mijloacelor fixe

[21] SMA Solar Technology AG - Inverter \& Photovoltaics solutions

[22] https://voltech.ro/on-grid-vs-off-grid/

[22] https://www.investopedia.com/terms/r/returnoninve stment.asp

[23] http://pvsol-online.valentin-software.com/\#/

[24] http://www.posharp.com/tsm-230pc05-solar-panelfrom-trina-solar_p1955443815d.aspx 